\title{
Leathesia difformis Extract Inhibits $\alpha$-MSH-Induced Melanogenesis in B16F10 Cells via Down-Regulation of CREB Signaling Pathway
}

\author{
Ga-Young Seo ${ }^{1}$, Yuna Ha ${ }^{1,2}$, Ah-Hyun Park ${ }^{1,2}$, Oh Wook Kwon ${ }^{1}$ and Youn-Jung Kim ${ }^{1,2,3, *(1)}$ \\ 1 Research Institute of Basic Sciences, Incheon National University, Incheon 22012, Korea; \\ tjrkdud7011@naver.com (G.-Y.S.); dbsk335@daum.net (Y.H.); dkgus3021@naver.com (A.-H.P); \\ hades770@hanmail.net (O.W.K.) \\ 2 Department of Cosmetic Science and Management, Graduate school, Incheon National University, \\ Incheon 22012, Korea \\ 3 Department of Marine Sciences, Incheon National University, Incheon 22012, Korea \\ * Correspondence: duckyj@inu.ac.kr; Tel.: +82-32-835-8861
}

Received: 27 December 2018; Accepted: 26 January 2019; Published: 28 January 2019

\begin{abstract}
Leathesia difformis (L.) Areschoug (L. difformis) is a species of littoral brown algae of the class Phaeophyceae. Only a few studies on the apoptotic, antiviral, and antioxidant properties of L. difformis have been reported, and its inhibitory effect on melanin synthesis has not been studied. The aim of this study was to investigate the anti-melanogenic effect of $L$. difformis extract on $\alpha$-melanocyte-stimulating hormone ( $\alpha-\mathrm{MSH})$-induced B16F10 melanocytes and its mechanism of action. L. difformis was extracted using $80 \%$ ethanol (LDE) and then fractioned between ethyl acetate (LDE-EA) and water (LDE-A). Our data demonstrated that LDE-EA significantly inhibited melanin level and cellular tyrosinase activity in $\alpha$-MSH-stimulated B16 cells. In addition, the expression of genes associated with melanin synthesis, such as microphthalmia-associated transcription factor (Mitf), tyrosinase (Tyr), tyrosinase-related protein-1 (Trp-1), dopachrome tautomerase (Dct), and melanocortin 1 receptor (Mc1r) was down-regulated by LDE-EA treatment. Moreover, LDE-EA decreased p-CREB levels, which suggests that the inhibition of the CAMP/PKA/CREB pathways may be involved in the anti-melanogenic effect of LDE-EA. Thus, this study revealed that LDE-EA is an effective inhibitor of hyperpigmentation through inhibition of CREB pathways and may be considered as a potential therapeutic agent for hyperpigmentation disorders.
\end{abstract}

Keywords: Leathesia difformis; melanogenesis; tyrosinase; CREB pathway; B16F10

\section{Introduction}

Melanocytes are located in the stratum basale of the epidermis. Melanocytes produce melanin in the melanosomes and transfer this to the keratinocytes, which gradually migrate to the outer layer of the skin. Human skin color is determined by the melanin content in the transferred keratinocytes [1,2]. In addition, melanin biosynthesis is crucial to enhance the body's defense against harmful effects of ultraviolet (UV) radiation and DNA damage to the skin [3,4]. However, excessive melanin production can lead to hyperpigmentation in the form of spots, freckles, and inflammation due to prolonged exposure to UV light $[5,6]$.

The regulation of melanogenesis is by growth factors, hormones, cytokines, and UV. When the skin (melanocytes) is exposed to UV light, keratinocytes produce adrenocorticotropic hormone, $\alpha$-melanocyte stimulating hormone ( $\alpha$-MSH), and endothelin- 1 , which indirectly increases the production of melanin [4,7], and $\alpha-\mathrm{MSH}$ subsequently binds to melanocortin-1 receptor (Mc1r), a G-protein-coupled membrane receptor expressed only in melanocytes and secreted from the middle 
cerebral pituitary gland to activate adenylate cyclase. This process amplifies intracellular cyclic adenosine monophosphate (cAMP) signaling and activates protein kinase A (PKA) and intracellular cAMP-response element binding (CREB) protein [8-10]. CREB activated through phosphorylation increases the expression of microphthalmia-associated transcription factor (MITF), which is specific to melanocyte transcription [11,12].

Melanin synthesis is regulated by enzymes such as tyrosinase, tyrosinase-related protein 1 (TRP-1), and dopachrome tautomerase (DCT). Tyrosinase is an enzyme that regulates the rate-limiting step of melanin production, which oxidizes 3,4-dihydroxy phenylalanine (DOPA) into dopaquinone. TRP-1 oxidizes 5,6-dihydroxyindole-2-carboxylic acid (DHICA) to red indole-5,6-quinone-2-carboxylic acid and regulates tyrosinase activity. DCT converts DOPA chrome to DHICA, which is subsequently converted into eumelanin and pheomelanin [13-15]. Therefore, in vitro assays that can efficiently measure the inhibition of activities of MITF, tyrosinase, TRP-1, and DCT are crucial for the evaluation of skin-whitening preparations [16].

The most commonly used whitening agents include hydroquinone, arbutin, kojic acid, ascorbic acid, and retinoic acid, but there are some reports that they can have toxic and allergic effects on the skin $[17,18]$. For example, hydroquinone inhibits tyrosinase activity in melanin formation and improves pigmentation and formation by interfering with the oxidation process of tyrosine in the early stages of melanin biosynthesis. However, it can cause skin irritation and contact dermatitis, and it has been reported that various side effects, such as ochronosis, are observed when used for a long period of time, and it is prohibited to use as a raw material for whitening products, and only a part thereof is used as a medicine by prescription [19-21]. In addition, kojic acid and ascorbic acid inhibit tyrosinase activity in melanin synthesis and inhibit the final stage of melanin production. However, it is not only low in skin penetration, stability, and whitening effect, but it can cause cytotoxicity, dermatitis, and erythema in long term use [22,23]. In this regard, there is an increasing need to develop safe and effective whitening agents with minimal side effects.

Seaweeds exert few toxic effects and contain various physiologically active substances; thus, they are widely used as medicines, health foods, and functional cosmetics. In particular, brown alga contains copious quantities of laminaran and fucoidan, polysaccharides known to exert anticancer, antioxidant, and blood coagulation effects. Studies on the skin-related activities of marine algae have been conducted in developed countries, such as the Netherlands, Norway, Germany, England, and France. These studies have emphasized the usefulness of marine algae as functional cosmetic materials [24]. Leathesia difformis (L.) Areschoug (L. difformis) is a yellowish-brown alga that is found attached to rocks or other plants. Fucoidan from L. difformis has apoptotic [25], antiviral [26], and antioxidant (DPPH radical scavenging and superoxide scavenging) properties [27]. However, the effects of L. difformis on melanin synthesis are still understudied.

The purpose of this study is to examine the effects of L. difformis extract on melanogenesis in vitro. For this, an $80 \%(v / v)$ ethanol $(\mathrm{EtOH})$ extract of $L$. difformis (LDE) was prepared, and then fractioned between ethyl acetate (EtOAc) (LDE-EA) and water (LDE-A). The melanin content and cellular tyrosinase activity of $\alpha$-MSH-stimulated B16F10 melanoma cells were evaluated. In addition, it was investigated the effects of L. difformis extract on molecular mechanisms involved in the expression of melanin biosynthesis-related genes and proteins in B16F10 melanoma cells.

\section{Results}

\subsection{Cytotoxicity of L. difformis Extracts in B16F10 Cells}

The cell viability was determined using the 3-(4,5-dimethylthiazol-2-yl)-2,5-diphenyltetra-zolium bromide (MTT) assay. To investigate whether the L. difformis extracts exerted a cytotoxic effect on melanoma cells, B16F10 cells were treated with various concentrations $(1-150 \mu \mathrm{g} / \mathrm{mL})$ of the extracts. For comparison of minimum cytotoxic concentration of $L$. difformis extracts, the $\mathrm{IC}_{20}$ values, which represents $20 \%$ inhibitory concentration of cell viability, was determined. From results, $\mathrm{IC}_{20}$ for 
LDE and LDE-EA was $59.12 \mu \mathrm{g} / \mathrm{mL}$ and $19.54 \mu \mathrm{g} / \mathrm{mL}$, respectively, while the $\mathrm{IC}_{20}$ of LDE-A was > $239.8 \mu \mathrm{g} / \mathrm{mL}$ at the highest dose (Figure $1 \mathrm{~A}-\mathrm{C}$ ). The results showed that LDE-A had no significant effect on the cell viability. However, the other fractions had a cytotoxic effect on the melanoma cells, although the effect was not significant, and LDE-EA was found to be more cytotoxic than LDE. As shown in Figure 1D,E, no cytotoxicity was observed for the B16F10 cells treated with concentrations of $\mathrm{LDE}$ of $<19.54 \mu \mathrm{g} / \mathrm{mL}$ for $72 \mathrm{~h}$. As a positive control, arbutin had no effect on the cell viability. From these results, the LDE concentrations of $1,5,10$, and $15 \mu \mathrm{g} / \mathrm{mL}$ were selected for further studies on the melanin content, cellular tyrosinase activity, and melanogenesis related-gene expression in the $\alpha$-MSH-stimulated B16F10 cells.
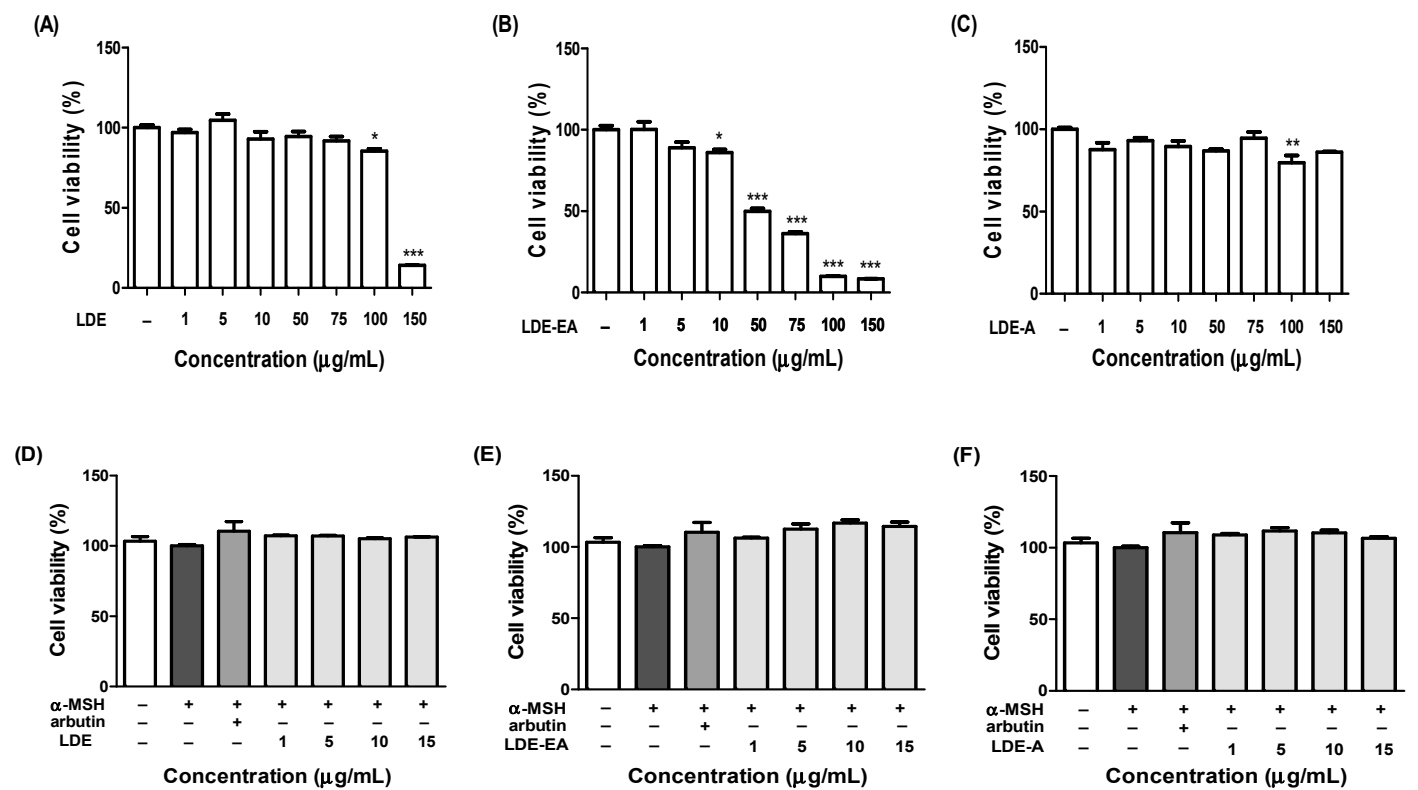

Figure 1. Effect of L. difformis extract on B16F10 melanoma cell viability. Cells were treated with various concentrations of LDE (A), LDE-EA (B), and LDE-A (C) for $24 \mathrm{~h}$, and were then treated with $200 \mathrm{nM}$ $\alpha$-MSH and 1, 5, 10, and $15 \mu \mathrm{g} / \mathrm{mL}$ of LDE (D), LDE-EA (E), and LDE-A (F) for $72 \mathrm{~h}$. Arbutin was used as a positive control at a concentration of $1 \mathrm{mM}$. Cell viability was measured by MTT assay. The results are represented as a percentage of control. Values are represented as the mean \pm SEM of three independent experiments; ${ }^{*} p<0.05,{ }^{* *} p<0.01$, and ${ }^{* * *} p<0.001$ versus control.

\subsection{Effects of L. difformis Extracts on the Melanin Synthesis}

To assess the inhibitory effect of the L. difformis extracts on melanin synthesis, we determined the melanin content of the B16F10 cells $72 \mathrm{~h}$ after treatment with three fractions of the extract concentration $(1,5,10$, and $15 \mu \mathrm{g} / \mathrm{mL})$. The inhibitory effect of the L. difformis extracts on the melanin content is shown in Figure 2, which is represented by images of B16F10 cell pellets lysed with $1 \mathrm{~N} \mathrm{NaOH}$ $(10 \%(v / v)$ DMSO). The melanin content of the $\alpha$-MSH-stimulated B16F10 cells treated with LDE-EA significantly decreased in a concentration-dependent manner (Figure 2B). Compared with the control, the melanin content ( $\%$ ) was $323.2 \%, 96.2 \%$, and $135.6 \%$ for the $\alpha$-MSH-stimulated control, positive control, and maximum concentration of LDE-EA, respectively. In addition, the color of the cell pellets lysed with $1 \mathrm{~N} \mathrm{NaOH}(10 \%(v / v)$ DMSO) was changed in a dose-dependent manner, as a result of the change in the melanin content (Figure 2B). However, LDE and LDE-A showed less inhibitory activity toward the melanin content than LDE-EA (Figure 2A,C). 
(A)

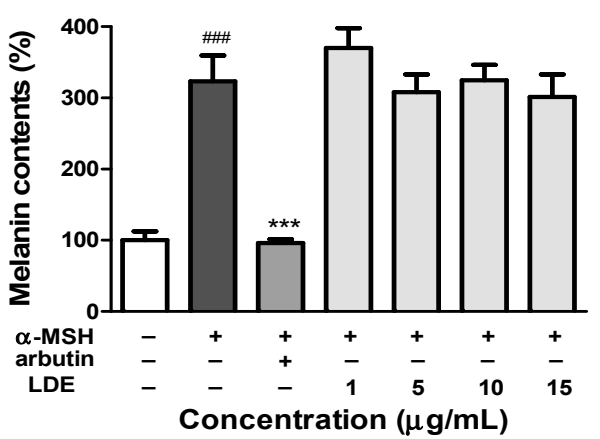

(B)

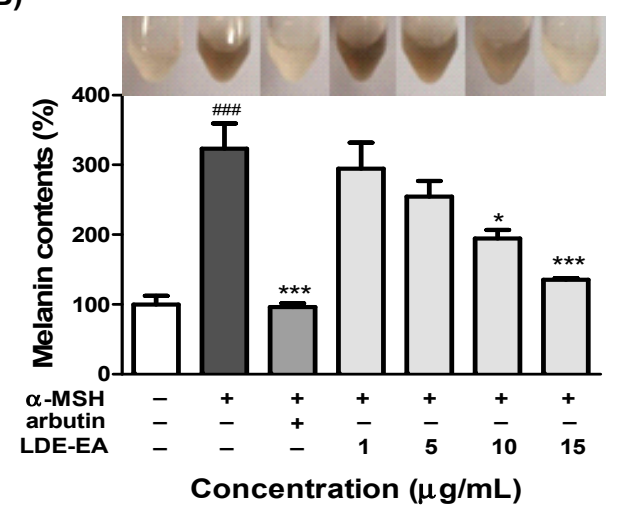

(C)

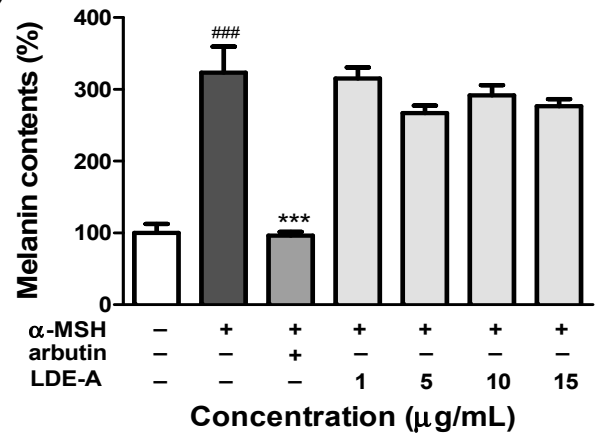

Figure 2. Effect of L. difformis extract on melanogenesis in B16F10 cells. B16F10 cells were exposed to $200 \mathrm{nM} \alpha$-MSH in the presence of 1, 5, 10, and $15 \mu \mathrm{g} / \mathrm{mL}$ L. difformis extract ((A) LDE, (B) LDE-EA, and (C) LDE-A) or $1 \mathrm{mM}$ arbutin (a melanin inhibitor). Each percentage value for the treated cells was reported relative to that of the control cells. Values are represented as the mean \pm SEM of three independent experiments. Note: \#\#\# $p<0.001$ compared with the control; ${ }^{*} p<0.05$, and ${ }^{* * *} p<0.001$ compared with the $\alpha$-MSH-treated control.

\subsection{Effects of the L. difformis Extracts on Tyrosinase Activity}

The effects of $L$. difformis extracts on the cellular tyrosinase activity in the $\alpha$-MSH-stimulated B16F10 melanoma cells are shown in Figure 3A-C. These results showed that LDE and LDE-A had no effect on the intracellular tyrosinase activity. However, the cellular tyrosinase activity was significantly inhibited by LDE-EA in a dose-dependent manner (Figure 3B). When compared to the control, the tyrosinase activity (\%) was $177.4 \%, 80.3 \%$, and $113.2 \%$ for the $\alpha$-MSH-stimulated control, arbutin as the positive control, and the maximum concentration of LDE-EA, respectively. These results were consistent with those that compared the effects of LDE-EA on the melanin content of B16F10 cells. 
(A)

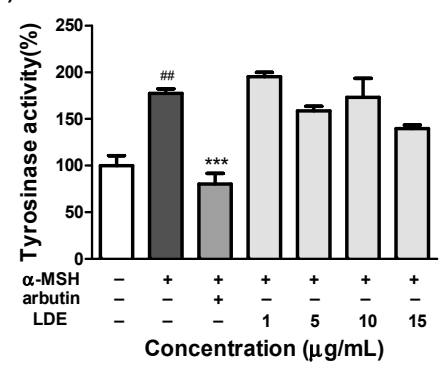

(B)

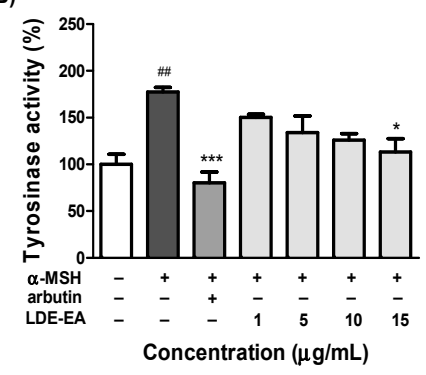

(C)

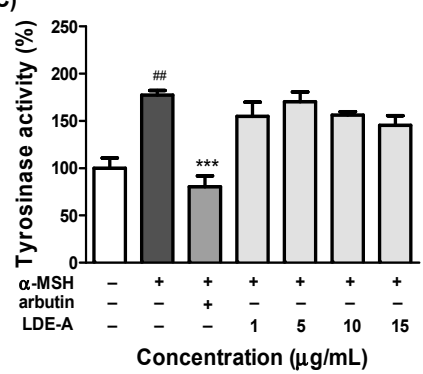

Figure 3. Effect of L. difformis extract on cellular tyrosinase activity in B16F10 cells. Cells were exposed to $200 \mathrm{nM} \alpha$-MSH in the presence of 1, 5, 10, and $15 \mu \mathrm{g} / \mathrm{mL}$ L. difformis extract ((A) LDE, (B) LDE-EA, and (C) LDE-A) or $1 \mathrm{mM}$ arbutin. Each percentage value for the treated cells was reported relative to that of the control cells. Values are represented as the mean \pm SEM of three independent experiments. Note: \#\# $p<0.01$ compared with the control; ${ }^{*} p<0.05$, and ${ }^{* * *} p<0.001$ compared with the $\alpha$-MSH-treated control.

\subsection{Effects of LDE-EA on Melanogenesis-Related Gene Expression}

To evaluate whether the $L$. difformis extracts affected the expression of melanogenesis-related genes, such as Tyr, Trp-1, Dct, Mitf, and Mc1r, gene expression was examined in $\alpha$-MSH melanoma cells using real-time qPCR. As the above experiments had shown that only LDE-EA had a significant effect on melanin synthesis, gene expression was only evaluated with this fraction. As shown in Figure 4, the mRNA levels of Trp-1, Dct, Mitf, and Mc1r decreased significantly in a dose-dependent manner, following treatment with $1,5,10$, and $15 \mu \mathrm{g} / \mathrm{mL}$ of LDE-EA. However, the tyrosinase mRNA expression was only reduced at the maximum concentration of $15 \mu \mathrm{g} / \mathrm{mL}$. In general, $\alpha$-MSH induces Mitf expression, and the Mitf downstream genes, such as Tyr, Trp-1, and Dct, increase melanogenesis. Therefore, these results suggested that LDE-EA down-regulates the expression of Tyr, Trp-1, Dct, Mitf, and Mc1r mRNA to affect melanogenesis in $\alpha$-MSH-stimulated melanoma cells.

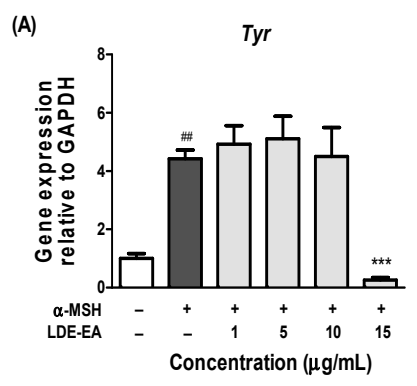

(D)

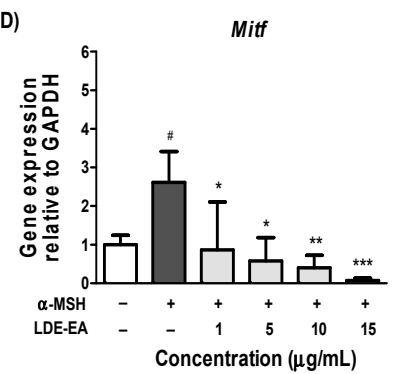

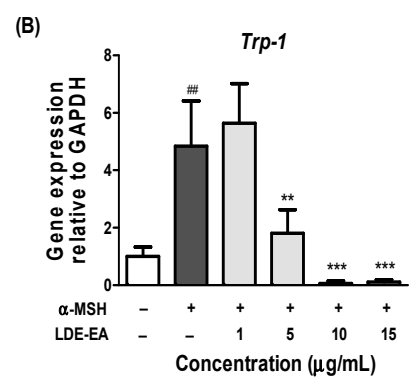
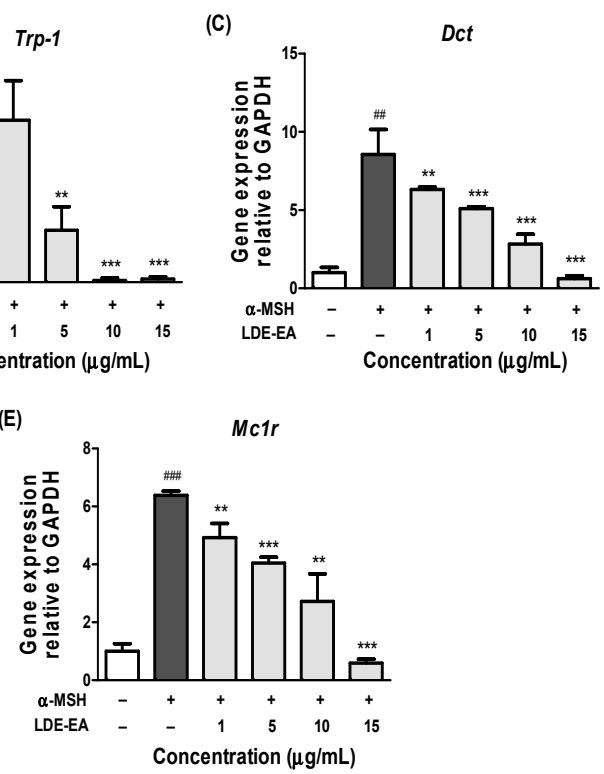

Figure 4. Effects of LDE-EA on mRNA expression of Tyr, Trp-1, Dct, Mitf, and Mc1r in B16F10 cells stimulated with $\alpha$-MSH. B16F10 cells were co-treated with LDE-EA and $200 \mathrm{nM} \alpha-\mathrm{MSH}$. After treatment, the mRNA expression of Tyr (A), Trp-1 (B), Dct (C), Mitf (D), and Mc1r (E) was measured and normalized to GAPDH expression. Values are represented as the mean \pm SEM of three independent experiments. Note: $\# p<0.05$, \#\# $p<0.01$, and \#\#\# $p<0.001$ compared with the control group; ${ }^{*} p<0.05$, ${ }^{* *} p<0.01$, and ${ }^{* * *} p<0.001$ compared with the $\alpha$-MSH-treated group. 


\subsection{Effects of LDE-EA on the Melanogenesis-Related Signaling Pathway}

It was observed that $\alpha$-MSH increases the transcriptional activity of MITF through the CAMP/CREB signaling pathway and promotes melanogenesis through the phosphorylation of MITF. To examine the phosphorylation activity of CREB in the CAMP/CREB pathway, due to LDE-EA treatment, a western blotting analysis for the expression of the p-CREB protein was implemented for the B16F10 cells treated with LDE-EA. As shown in Figure 5A-C, the protein level of $\beta$-actin, used as an internal control, showed no change. The total amount of the CREB protein decreased slightly at 10 and $15 \mu \mathrm{g} / \mathrm{mL}$. The phosphorylation of CREB was down-regulated after a high dose of treatment with LDE-EA. Also, because LDE-EA inhibited melanin synthesis and tyrosinase expression, we evaluated if LDE-EA is reduced the production of cAMP, which induces the expression of MITF, in B16 melanoma cells. As shown in Figure 5D, we found that cAMP levels were decreased by LDE-EA in a dose dependent manner. These results indicate that the inhibitory effect of LDE-EA on melanin synthesis can be mediated to MITF degradation via the cAMP/PKA/CREB pathway.
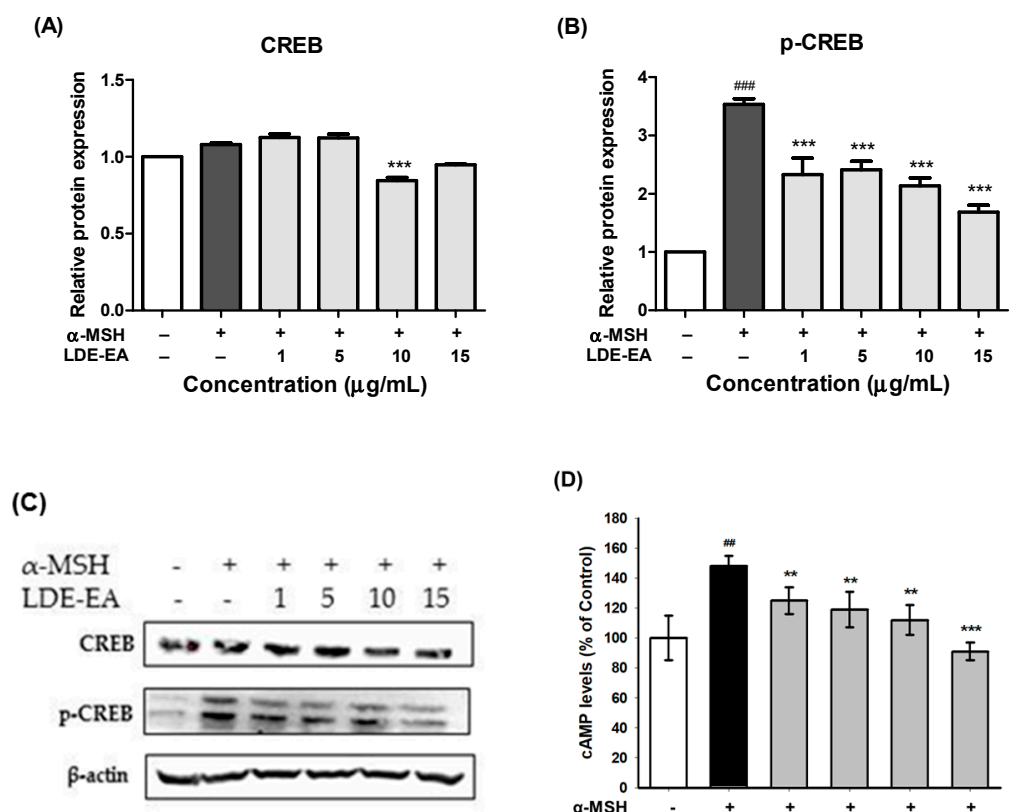

(D)

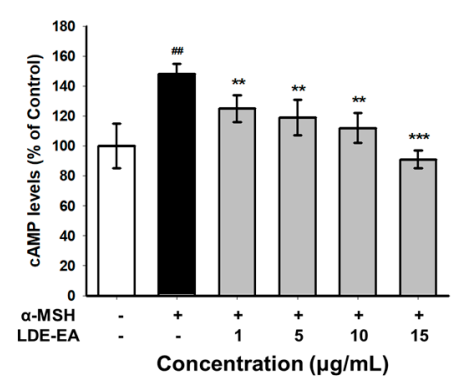

Figure 5. Effects of LDE-EA on protein expression of p-CREB and cAMP levels in B16F10 cells. Cells (1 $\times 10^{5}$ cells $/ \mathrm{mL}$ ) were cultured for $24 \mathrm{~h}$, and treated with LDE-EA and $200 \mathrm{nM} \alpha$-MSH for 3 days. After treatment, total cell lysates were assayed by western blot analysis using antibodies for CREB $(A, C)$ and p-CREB (B,C). Equal amounts of protein loading were checked using $\beta$-actin antibodies. (D) The total amount of cellular cAMP was assayed using the immunoassay kit. Values are represented as the mean \pm SEM of three independent experiments. Note: \#\# $p<0.001$ and \#\# $p<0.01$ compared with the control group; ${ }^{* *} p<0.001$ and ${ }^{* *} p<0.01$ compared with the $\alpha$-MSH-treated group.

\subsection{Analysis of Fucoxanthin in LDE-EA by HPLC}

Fucoxanthin ( $3^{\prime}$-acetoxy-5,6-epoxy-3,5'-dihydroxy- $6^{\prime}, 7^{\prime}$-didehyro-5,6,7,8, $5^{\prime}, 6^{\prime}$-hexahydro- $\beta, \beta$ carotene-8-one) is a carotenoid with various bioactive properties found in brown algae. The chromatogram of LDE-EA fraction is shown in Figure 6. The observed peak was assigned as fucoxanthin by comparing their retention time with standard compound in LDE-EA extract in the chromatogram at $280 \mathrm{~nm}$. There are $0.15 \mathrm{~g}$ fucoxanthin per $1 \mathrm{~kg}$ of the extract. As can be seen in Figure 6, there is also another major compound besides the peak of fucoxanthin, which could be another bioactive component of this extract. 
(A)

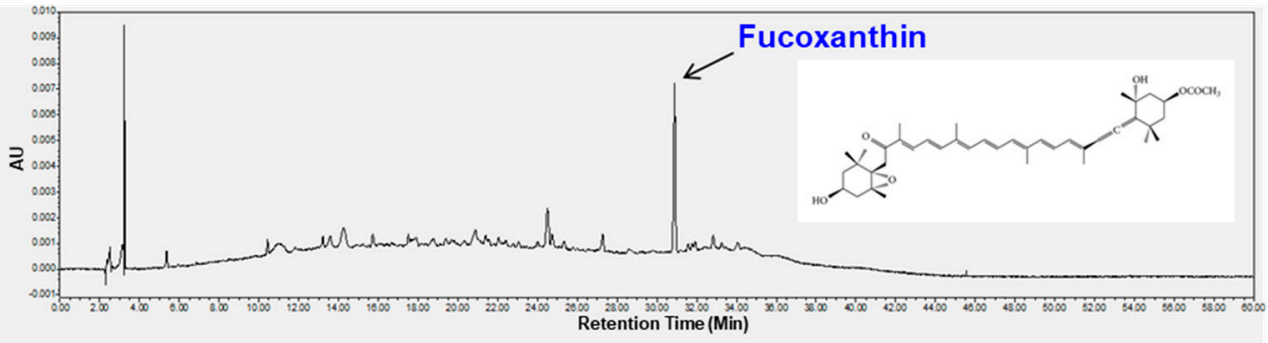

(B)

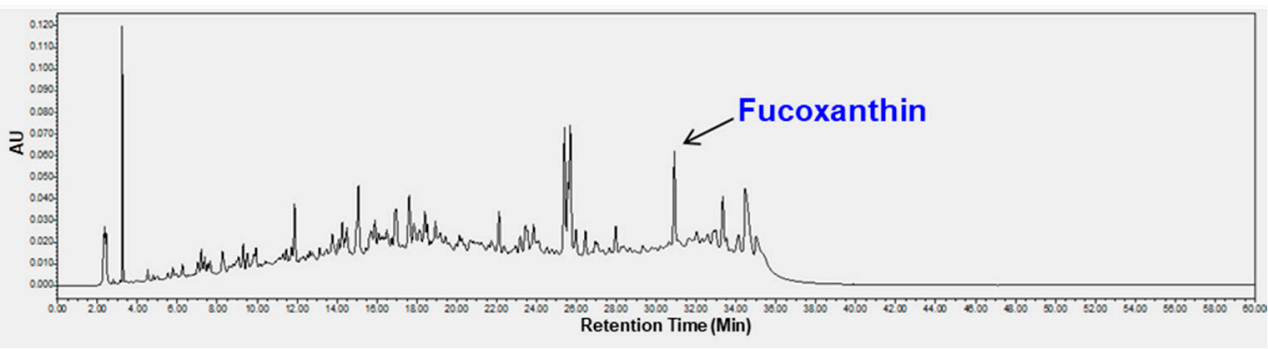

Figure 6. High-performance liquid chromatography (HPLC) chromatograms of (A) the fucoxanthin standard (B) EtOAc fraction of L. difformis EtOH extract (LDE-EA). AU indicates the absorbance unit.

\section{Discussion}

In recent years, cosmetics, health foods, and drugs, including those containing algae-derived ingredients, are preferred due to the various bioactive compounds, as well as the rich source of nutrients [28-30]. In particular, brown algae are rich in physiologically active ingredients, such as fucoidan, pyropheophytin, and phlorotannin, and are used in various fields around the world. For example, fucoidan is used for hyperpigmentation or is used as a functional cosmetic material. Likewise, although the components of brown algae have been used in various fields, since their antioxidant, anti-inflammatory, anti-cancer, and anti-whitening effects have been revealed [31-34], there has been no research on the whitening effect of $L$. difformis, which is a type of brown algae, and the regulation of the melanin synthesis pathway. Therefore, we investigated the potential anti-melanogenesis properties of the L. difformis extracts (LDE, LDE-EA, and LDE-A), and the whitening effects of the extract on the melanin synthesis pathway were examined.

In this study, several fractions of L. difformis were investigated for their inhibitory effect on the melanin synthesis pathway and compared with arbutin as a positive control. Melanin is produced by a series of enzymatic reactions that involve Mitf, Trp-1, and Dct, with tyrosinase being the most important component of this process. Tyrosinase, which catalyzes the early stage of melanin biosynthesis, is converted to DOPA and dopaquinone in order to synthesize eumelanin and pheomelanin $[35,36]$. To confirm the effect of the L. difformis extracts on cellular melanogenesis, cell viability assays were performed to determine the concentration of the L. difformis extracts that did not cause cytotoxicity. Cells were treated with $0-150 \mu \mathrm{g} / \mathrm{mL}$ of the L. difformis extracts, and cytotoxicity was observed for LDE-EA in a concentration-dependent manner (Figure 1A-C). In the case of LDE, cytotoxicity of $14.02 \%$ was observed at the highest concentration, while LDE-A showed no cytotoxicity. Based on these results, treatment with the $L$. difformis extract at $0-15 \mu \mathrm{g} / \mathrm{mL}$ for $72 \mathrm{~h}$ showed no cytotoxicity (Figure 1D-F). For the comparative analysis, the concentrations for subsequent assays were therefore set at 1, 5, 10, and $15 \mu \mathrm{g} / \mathrm{mL}$.

Melanin production by the B16F10 cells, following treatment with 1,5,10, and $15 \mu \mathrm{g} / \mathrm{mL}$ of the $L$. difformis extract, was reduced in a concentration-dependent manner without cytotoxicity, with only LDE-EA (Figure 2). When the data were expressed as the percentage normalized to the non-treated cells, the cells treated with $\alpha$-MSH, arbutin, and the LDE-EA showed $323.2 \%, 96.2 \%$, and $135.6 \%$ melanin production, respectively. The inhibitory effect of the L. difformis extract on melanin production was similar to that of the positive control arbutin, and the inhibition of the intracellular tyrosinase activity, which is implicated in melanin production, was also confirmed (Figure 3). Similar to the 
melanin production assay, the inhibition activity of the L. difformis extract was confirmed only for LDE-EA. These results demonstrate that LDE-EA inhibits melanin synthesis and down-regulates tyrosinase activity in $\alpha-\mathrm{MSH}$ induced B16F10 cells.

To elucidate the mechanisms involved in the inhibition of melanin biosynthesis by L. difformis, we examined possible LDE-EA influences on the mRNA expression of melanogenesis-related genes and CREB activation. Generally, melanin is synthesized through several intracellular signal transduction pathways. As the primary mechanism for melanin synthesis, the cAMP/PKA pathway induces the expression of proopiomelanocortin (POMC) in keratinocytes when the skin is exposed to UV light. Increased levels of $\alpha$-MSH then bind to the Mc1r receptor that is present in the cell membrane of melanocytes; this results in an increase in cAMP and the activation of PKA, a downstream signaling molecule, which increases Mitf expression through CREB. Mitf promotes the expression of tyrosinase, Trp-1, and Dct as important transcription factors for melanin synthesis [4,37-41]. Therefore, it is important to confirm the inhibition of LED-EA on melanogenesis by examining the down-regulation of MITF, tyrosinase, Trp-1, and Dct expression. Our results indicate that LDE-EA effectively down-regulated the mRNA expression of Tyr, Trp-1, Dct, Mitf, and Mc1r, suggesting that LED-EA does not directly inhibit tyrosinase activity. This effect can be explained by down-regulation of Tyr, Trp-1, and Dct through the inhibition of Mitf expression in B16F10 cells.

Furthermore, to evaluate the particular signaling pathway for melanogenesis, total CREB and the phosphorylation status of CREB were assessed by Western blot. Our data showed that the p-CREB level was decreased in the LDE-EA-treated melanoma cells. Also, we measured the intracellular cAMP levels in B16F10 cells stimulated by $\alpha$-MSH. LDE-EA led to significant inhibition of cAMP levels in B16F10 cells stimulated by $\alpha-\mathrm{MSH}$ (Figure 5D). These results indicate that LDE-EA can induce anti-melanogenesis through a cAMP dependent CREB-mediated pathway in B16F10 cells stimulated by $\alpha$-MSH.

Transcriptional regulation of tyrosinase is mainly dependent on level of MITF, and MITF is up-regulated by CREB. Phosphorylated CREB up-regulates MITF, which binds to M-box and E-box motifs in the promoter of target genes related to melanin production [38]. Therefore, to examine whether LED-EA activates/inhibits CREB pathways, we assessed total CREB and the phosphorylation status of CREB by Western blot. Our data showed that the LDE-EA significantly inhibited activation of CREB. These results suggest that CREB signaling can play an important role in anti-melanogenesis of LED-EA treated B16F10 cells.

Previously, many types of brown algae-derived phytochemicals with hypopigmenting effects, including phlorotannins, carotenoids, meroterpenoids, and sulfated polysaccharides, have been reported [42]. Phlorotannins, derivatives of phloroglucinol (1,3,5-trihydroxybenzene), are polyphenolic compounds found only in brown algae [43]. Among these phlorothannins, eckol and dieckol from Ecklonia cava and 4-hydroxyphenethyl alcohol from Hizikia fusiformis were isolated from EtOAc fraction of $\mathrm{MeOH}$ or EtOH extract, respectively [44,45]. However, meroterpenoid compounds are mainly isolated from EtOH extract of the Sargassum genus [46,47] and fucoidan, a fucose-rich sulfated polysaccharide, is included in the crude extract of Fucus vesiculosus [48]. Fucoxanthin, which is one of carotenoids, was identified in organic solvent extracts, such as acetone [49].

Among these phytochemicals, fucoxanthin is a yellowish-brown pigment, which constitutes $\sim 70 \%$ of the carotenoid found in brown algae [50]. Fucoxanthin is reported to have anti-oxidative, anti-inflammatory, anti-cancer, and anti-obese properties [51-54]. Also, anti-melanogenic activities of fucoxanthin were documented by Simoda et al. [55]. Therefore, we determined whether fucoxanthin is one of the constituents of LDE-EA through HPLC analysis. HPLC analysis of LDE-EA showed that LDE-EA includes fucoxanthin (Figure 6). Although our results suggest that the anti-melanogenic effect of LDE-EA on B16F10 cells may be attributed to fucoxanthin, other compounds present in LDE-EA may also have an effect on the overall ability to inhibit melanogenesis. In the present study, LED-EA was isolated from EtOAc fraction of the L. difformis EtOH extract, and it is similar with protocols used for isolation of phlorotannins in above mentioned literature studies [44,45]. Through further study, 
it is expected to be able to identify more complex derivatives of phlorotannins, such as eckol, with hypopigmenting effects. Even though this analyzed data is preliminary, it is crucial because there has been no report about $L$. difformis EtOAc extract regarding effect on anti-melanogenesis.

In addition, understanding the molecular mechanisms of a bioactive compound in specific targets is very important for its proper application. However, there are limited reports on detailed molecular events and specific targets for the anti-melanogenic effects of these brown algae-derived compounds. As reported in previous literature studies, fucoxanthin from Laminaria Japonica suppresses Pge2, Msh, and Trp-1, and melanogenic stimulant receptors, p75 neurotrophin receptor (NTR), prostaglandin EP1 receptor (EP1), and MC1R in UV-irradiated mice [55]. Dioxinodehydroeckol, a phlorotannin isolated from Ecklonia stolonifera, is involved in hypopigmentation by phosphatidylinositol 3-kinase (PI3K)/AKT-mediated down-regulation of Mitf [56]. It is reported that octaphlorethol A from Ishige foliacea inhibits melanogenesis by the extracellular signal-regulated kinase (ERK) 1/2-mediated down-regulation of Mitf, Tyr, Trp-1, and Trp-2 in B16F10 cells [57]. Fucoidan, a fucose-rich sulfated polysaccharide isolated from Fucus vesiculosus, is involved in hypopigmentation by ERK-mediated down-regulation of Mitf in Mel-Ab cells [58]. Azam et al. elucidated that ethanolic extract from Sargassum serratifolium included three active meroterpenoid compounds, namely sargahydroquinoic acid, sargaquinoic acid, and sargachromenol, and this extract inhibited hyperpigmentation in B16F10 cells through regulation of Mitf via CAMP/CREB and ERK signaling pathways [47]. In this study, it is elucidated that LDE-EA from L. difformis can inhibit the melanogenesis by the decreased gene expression of Tyr, Trp-1, and Dct through the inhibition of Mitf expression via cAMP/CREB signaling pathway regulation (Figure 7).

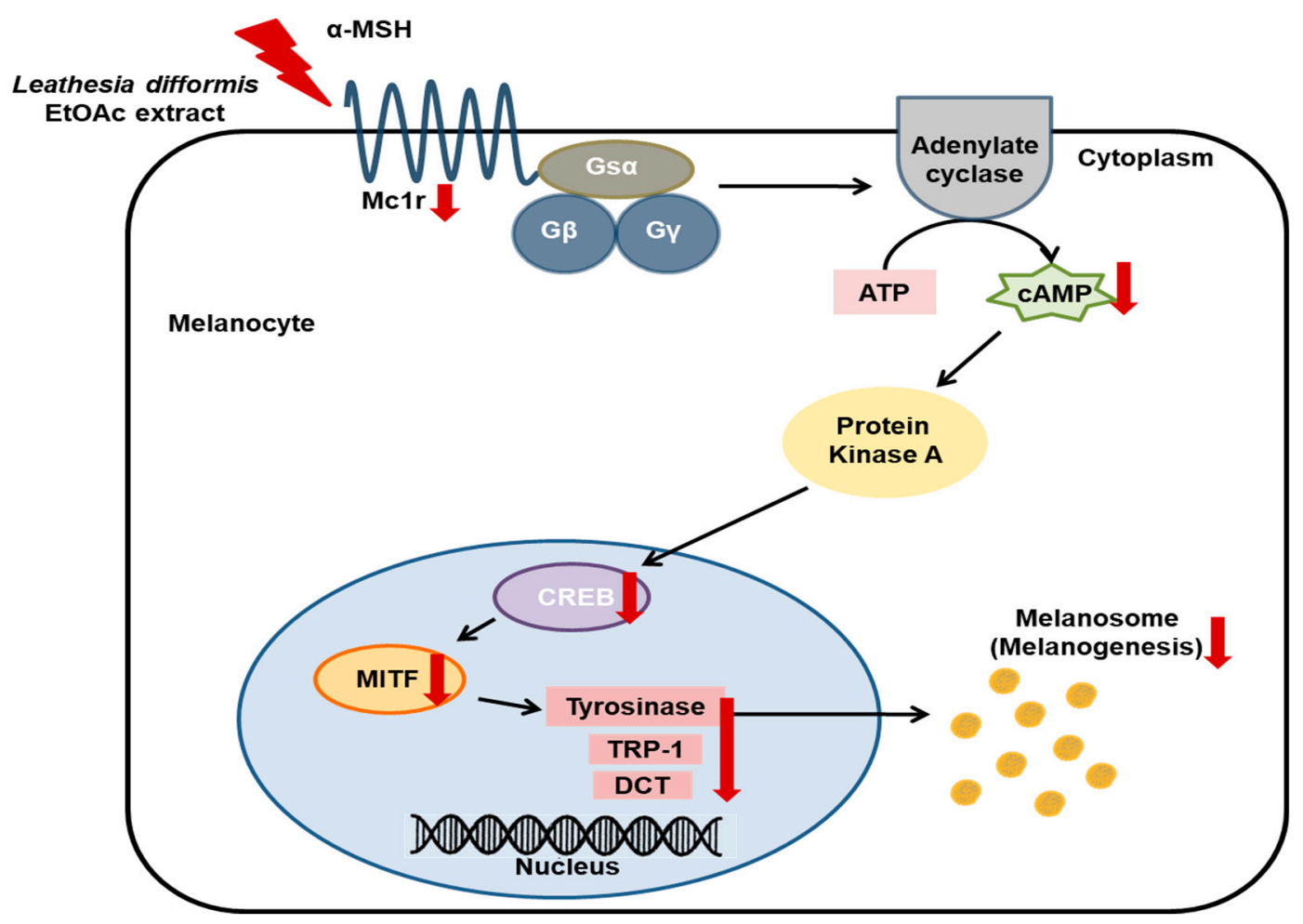

Figure 7. Proposed mechanism of EtOAc extract of L. difformis (LDE-EA) for inhibition of $\alpha$-MSH-induced melanogenesis. Red polyline arrow indicates the treatment to melanocyte. Red arrows indicate the activity of LDE-EA and black arrows indicate the direction of regulation.

This study is worthy of being the first study to identify the mechanism on anti-melanogenic effect of L. difformis, a brown alga is yet not elucidated the mechanism of action. Moreover, it is important to present the possibility of the identification of a new potential compound with 
hypopigmenting activity. Therefore, LDE-EA may be considered a potential therapeutic agent for the treatment of skin-pigmentation related diseases and may be a useful component in the skin-whitening cosmetic industry.

\section{Materials and Methods}

\subsection{Chemicals and Reagents}

Dimethyl sulfoxide (DMSO), $\alpha-\mathrm{MSH}, \mathrm{NaOH}, \mathrm{MTT}$, arbutin, synthetic melanin, Triton X-100, radioimmunoprecipitation assay (RIPA) buffer, skim milk, Tween 20, L-DOPA, and fucoxanthin analytical standard were obtained from Sigma-Aldrich (St. Louis, MO, USA). Dulbecco's modified Eagle's medium (DMEM), fetal bovine serum (FBS), penicillin/streptomycin, trypsin-ethylenediaminetetraacetic acid, TRIzol solution, and bicinchoninic acid (BCA) protein assay kit were purchased from Thermo Fisher Scientific (Waltham, MA, USA). Antibodies against CREB, p-CREB, $\beta$-actin, and anti-rabbit horseradish peroxidase antibody were purchased from Cell Signaling Technology (Danvers, MA, USA). Primers against Tyr, Trp-1, Dct, Mitf, Mc1r, and GAPDH genes were synthesized by Bioneer (Daejeon, Korea). An enhanced chemiluminescence (ECL) kit and polyvinylidene fluoride (PVDF) membrane were obtained from Bio-Rad (Hercules, CA, USA). EtOH and EtOAc from DaeJung Chemicals and Metals Co., Ltd. (Siheung, Korea) were analytical grade.

\subsection{Preparation of L. difformis Extract}

The L. difformis powder was purchased from PARAJEJU (Jeju, Korea). L. difformis extract was prepared with modification of extraction protocol by Kang et al. [44]. For the EtOH extract, the powdered L. difformis (1 kg dried weight) was first soaked with $80 \%(v / v) \mathrm{EtOH}(10 \mathrm{~L})$ in deionized water (D.W.) at room temperature for $24 \mathrm{~h}$. Then, it was filtered by Whatman filter paper and the solvents of filtrates were evaporated by the vacuum rotary evaporator. After freeze-drying, the $80 \%$ $\mathrm{EtOH}$ extract from L. difformis was lyophilized to yield $232 \mathrm{~g}$ of extract. The extract was partitioned between to EtOAc-water $(1: 1$ ratio, $w / v)$ to give EtOAc-soluble fraction and water soluble fraction. The EtOAc fraction was concentrated in a rotary evaporator. The EtOAc and water fractions were dried using vacuum evaporator to obtain $10.61 \mathrm{~g}$ of EtOAc and $178.2 \mathrm{~g}$ of $\mathrm{H}_{2} \mathrm{O}$, respectively. The L. difformis extracts were dissolved in DMSO.

\subsection{Cell Culture}

The mouse melanoma cell line B16F10 (CRL-6475) was purchased from American Type Culture Collection (ATCC, Rockville, MD, USA) and maintained in a humidified atmosphere of $5 \% \mathrm{CO}_{2}$ and $95 \%$ air at $37^{\circ} \mathrm{C}$. The culture medium used was DMEM supplemented with $10 \%(v / v)$ heat-inactivated fetal bovine serum plus $100 \mathrm{U} / \mathrm{mL}-100 \mu \mathrm{g} / \mathrm{mL}$ penicillin-streptomycin. The medium was renewed every two days.

\subsection{Cell Viability Assay}

Cell viability was determined by the MTT assay. B16F10 cells were plated into a 96-well plate at a density of $5 \times 10^{4}$ cells $/ \mathrm{mL}$ for $24 \mathrm{~h}$ and treated with various concentrations from 1 to $150 \mu \mathrm{gg} / \mathrm{mL}$ of $L$. difformis extract for $24 \mathrm{~h}$ at $37{ }^{\circ} \mathrm{C}$ in $95 \%$ humidified air and $5 \% \mathrm{CO}_{2}$. To compare cells with melanin contents assay, the cells were seeded in a 24-well plate at a concentration of $1 \times 10^{4}$ cells $/ \mathrm{mL}$ for $72 \mathrm{~h}$. Following the incubation, the cells were treated with MTT $(0.5 \mathrm{mg} / \mathrm{mL}$ in phosphate-buffer saline, PBS) for $3 \mathrm{~h}$. The medium was then removed and $1 \mathrm{~mL}$ of DMSO was added into each well to dissolve formazan crystals, the metabolite of MTT. After thoroughly mixing, the absorbance was measured at $570 \mathrm{~nm}$ using a microplate reader that is directly correlated with cell quantity. The percentage of cells showing cytotoxicity was determined relative to the control group. 


\subsection{Measurement of Melanin Contents}

Melanin contents was executed as described, with minor modifications [59]. The B16F10 melanoma cells were seeded at a density of $2 \times 10^{4}$ cells per $\mathrm{mL}$ in 24 -well culture plates and then incubated for $24 \mathrm{~h}$. The cells were exposed to various concentrations $(1,5,10$, and $15 \mu \mathrm{g} / \mathrm{mL})$ of the L. difformis extracts or $1 \mathrm{mM}$ arbutin for $72 \mathrm{~h}$ in the presence or absence of $200 \mathrm{nM} \alpha-\mathrm{MSH}$. The cells were washed twice in phosphate-buffered saline and lysis dissolved in $1 \mathrm{~N} \mathrm{NaOH}$ (in 10\% (v/v) DMSO in D.W.) by $1 \mathrm{~h}$ at $80^{\circ} \mathrm{C}$. The absorbance at $405 \mathrm{~nm}$ was measured using a microplate reader. The melanin contents were determined from a standard curve prepared from an authentic standard of synthetic melanin. In addition, the melanin contents were determined based on the absorbance/ $\mu \mathrm{g}$ of protein in the extract from each cell. The protein concentration was determined by the BCA protein assay kit using BCA as a standard.

\subsection{Cellular Tyrosinase Activity}

Cellular tyrosinase activity was determined as described previously, with slight modifications [60]. The culture method for determining cellular tyrosinase assay was similar to that for determining melanin contents. The B16F10 melanoma cells were seeded at a density of $2 \times 10^{4}$ cells $/ \mathrm{mL}$ in 24 -well culture plates and then incubated for $24 \mathrm{~h}$. Cells were then exposed to increasing doses of $L$. difformis extracts or arbutin for $72 \mathrm{~h}$ in the presence or absence of $200 \mathrm{nM} \alpha-\mathrm{MSH}$. The cells were then washed with phosphate buffered saline (pH 6.8) and lysed with $1 \%(v / v)$ Triton X-100. The pellet solutions were frozen and thawed three times and then centrifuged at $13,000 \mathrm{rpm}$ for $15 \mathrm{~min}$ at $4{ }^{\circ} \mathrm{C}$. The protein concentration was determined by the BCA protein assay kit using BCA as a standard. The reaction mixture consisting of $40 \mu \mathrm{g}$ protein (adjusted to $100 \mu \mathrm{L}$ with $1 \%$ Triton X-100) and $100 \mu \mathrm{L}$ of $5 \mathrm{mM}$ L-DOPA was added to each well of a 96-well plate. After incubation at $37^{\circ} \mathrm{C}$ for $1 \mathrm{~h}$, the optical density at $475 \mathrm{~nm}\left(\mathrm{OD}_{475}\right)$ was measured using a microplate reader. Tyrosinase activity in the protein was calculated by the following formula:

$$
\text { Tyrosinase activity }(\%)=\left(\frac{\mathrm{OD}_{475} \text { of with extract treatment }}{\mathrm{OD}_{475} \text { of without extract treatment }}\right) \times 100
$$

\subsection{RNA Isolation and Real-Time PCR}

The expressions of Tyr, Trp-1, Dct, Mitf, and Mc1r genes were determined by real-time PCR using glyceraldehyde 3-phosphate dehydrogenase (Gapdh) as an internal positive control. Melanoma cells $\left(1 \times 10^{5}\right.$ cells $\left./ \mathrm{mL}\right)$ were plated on 6 -well plates and incubated. Then, the cells were treated with various concentrations of L. difformis extracts for $24 \mathrm{~h}$ in the presence or absence of $200 \mathrm{nM}$ of $\alpha-\mathrm{MSH}$. The cells were harvested and washed twice with PBS. Total cellular RNA was prepared using TRIzol solution according to the manufacturer's instructions. RNA was converted to cDNA using ReverTra Ace ${ }^{\circledR}$ qPCR RT master mix with gDNA remover (TOYOBO, Osaka, Japan), according to the manufacturer's instructions. The THUNDERBIRD SYBR ${ }^{\circledR}$ qPCR Mix (TOYOBO, Osaka, Japan) was used in all the samples and reactions were carried out in a $15 \mu \mathrm{L}$ final reaction volume. Each experiment was performed at least twice in duplicates using $10 \mu \mathrm{g}$ of the following primers in Table 1. 
Table 1. Sequences of the primer pairs of specific target genes.

\begin{tabular}{ccc}
\hline Target Gene & Sequence \\
\hline \multirow{2}{*}{ Tyr } & $\begin{array}{c}\text { Forward } \\
\text { Reverse }\end{array}$ & $\begin{array}{c}\text { AAGAATGCTGCCCACCATGG } \\
\text { CACGGTCATCCACCCCTTTG }\end{array}$ \\
\hline \multirow{2}{*}{ Trp -1} & $\begin{array}{c}\text { Forward } \\
\text { Reverse }\end{array}$ & CAGTGCAGCGTCTTCCTGAG \\
& TTCCCGTGGGAGCACTGTAA \\
\hline \multirow{2}{*}{ Forward } & Reverse & ATAAGGCGTGCTGAACAAGGA \\
& Forward & ATCCCATCCACCGGTCTCTG \\
\multirow{2}{*}{ Mitf } & Reverse & CCGTCCGTGAGATCCAGAGT \\
\hline \multirow{2}{*}{ Mc1r } & Forward & TCATCGTCCTCTGCCCTCAG \\
& Reverse & GCAGCACCTCCTTGAGTGTC \\
\hline \multirow{2}{*}{ Gapdh } & Forward & TTGGCATTGTGGAAGGGCTC \\
& Reverse & ACCAGTGGATGCAGGGATGA \\
\hline
\end{tabular}

\subsection{Western Blot Analysis}

B16F10 cells $\left(1 \times 10^{5}\right.$ cells $\left./ \mathrm{mL}\right)$ were treated with different concentration of $L$. difformis on 6-well plates. After treatment, the cells were collected and lysed using RIPA buffer. The lysates as protein sample were denatured at $95^{\circ} \mathrm{C}$. Protein concentrations of cell lysates were determined by the protein assay kit. Equal amounts of protein were separated using 10\% $(w / v)$ SDS-polyacrylamide gel electrophoresis (SDS-PAGE) running gel and transferred to a polyvinylidene fluoride (PVDF) membrane. The membrane was blocked using $5 \%(w / v)$ skim milk with Tris buffered saline containing $0.05 \%(v / v)$ Tween 20 (TBS-T). Membranes were incubated with different primary antibodies for overnight including CREB, p-CREB (1:2000), and $\beta$-actin (1:3000), and further incubated with anti-rabbit horseradish peroxidase antibody for $1 \mathrm{~h}$. The bands of bound antibodies were detected by enhanced chemiluminescence reagents. Loading control was assessed using anti- $\beta$-actin antibody. All determinations were performed in triplicate.

\section{9. cAMP Measurement Assay}

The cAMP levels were measured using a cAMP ELISA kit (Cayman Chemical, Ann Arbor, MI, USA). Briefly, B16F10 cells $\left(3 \times 10^{5}\right)$ were lysed in $0.1 \mathrm{M} \mathrm{HCl}$ to inhibit the phosphodiesterase activity. The supernatants were then collected, neutralized, and diluted. After neutralization and dilution, a fixed amount of cAMP conjugate was added to compete with cAMP in the cell lysate for sites on rabbit polyclonal antibody immobilized on a 96-well plate. After washing to remove excess conjugated and unbound cAMP, substrate solution was added to the wells to determine the activity of the bound enzyme. The color development was then stopped, after which the absorbance was read at $415 \mathrm{~nm}$. The intensity of the color was inversely proportional to the level of cAMP in the cell lysate.

\subsection{HPLC Analysis}

The HPLC analysis was carried out on a Waters system (Waters Corp., Milford, MA, USA), consisting of a separation module (e2695) with an integrated column heater, an autosampler, and a photodiode array detector (2998). UV absorbance was monitored at 200 to $400 \mathrm{~nm}$. Quantification was carried out by integration of the peak areas at $280 \mathrm{~nm}$. The sample and standard injection volume was $10 \mu \mathrm{L}$. A C18 column $(250 \times 4.6 \mathrm{~mm}$; particle size, $5 \mathrm{um}$; YMC Co. Ltd., Kyoto, Japan $)$ was installed in a column oven and maintained at $30^{\circ} \mathrm{C}$. The mobile phase was composed of water containing $0.5 \%$ $(v / v)$ tri-fluoro acetic acid (solvent A) and acetonitrile (solvent B). The flow rate was $1.0 \mathrm{~mL} / \mathrm{min}$. The gradient was $20 \% \mathrm{~A}$ and $80 \% \mathrm{~B}$. LDE-EA and fucoxanthin were used as sample and standard at a concentration of $10 \mathrm{mg} / \mathrm{mL}$ and $10 \mu / \mathrm{mL}$ of each materials for HPLC analysis to identify the peaks. 


\subsection{Statistical Analysis}

The data were analyzed by using Statistical Analysis System (SAS) software (PRISM) (GraphPad Software, San Diego, CA, USA). All data are expressed as mean \pm S.E.M. Statistical comparisons between different treatments were performed by using one-way ANOVAs with Tukey's multiple comparison post-hoc tests. The $*$-values $<0.05$ indicated a statistical significance.

\section{Conclusions}

This study demonstrated, for the first time, the inhibitory effects of $L$. difformis extracts on melanin biosynthesis. The major finding is that LDE-EA can inhibit the melanogenesis by the decreased gene expression of Tyr, Trp-1, and Dct through the inhibition of Mitf expression. In addition, LDE-EA exerts an inhibitory effect on melanogenesis through cAMP/CREB signaling pathway regulation (Figure 7). Therefore, LDE-EA may be considered a potential therapeutic agent for the treatment of skin-pigmentation related diseases and may be a useful component in the skin-whitening cosmetic industry.

Author Contributions: Conceptualization, Y.-J.K. and G.-Y.S.; methodology, G.-Y.S., O.W.K., and Y.H.; software, G.-Y.S. and Y.H.; validation, G.-Y.S. and A.-H.P.; investigation, Y.-J.K. and G.-Y.S.; resources, G.-Y.S., A.-H.P., and Y.H.; data curation, Y.-J.K., O.W.K., and G.-Y.S.; writing-original draft preparation, G.-Y.S.; writing-review and editing, Y.-J.K. and G.-Y.S.; visualization, Y.-J.K. and G.-Y.S.; supervision, Y.-J.K.; project administration, Y.-J.K.; funding acquisition, Y.-J.K.

Funding: This study was supported by the Basic Science Research Program through the National Research Foundation of Korea (NRF), funded by the Ministry of Education [NRF-2017R1A6A1A06015181] and by Incheon National University Research Grant in 2014.

Conflicts of Interest: The authors declare no conflict of interest.

\section{Abbreviations}

$\begin{array}{ll}\text { L. difformis } & \text { Leathesia difformis (L.) Areschoug } \\ \alpha \text {-MSH } & \alpha \text {-melanocyte stimulating hormone } \\ \text { LDE } & \text { extract of L. difformis using 80\% ethanol } \\ \text { LDE-EA } & \text { ethyl acetate fraction of LDE } \\ \text { LDE-A } & \text { water fraction of LDE } \\ \text { Mitf } & \text { microphthalmia-associated transcription factor } \\ \text { Tyr } & \text { tyrosinase } \\ \text { Trp-1 } & \text { tyrosinase-related protein-1 } \\ \text { Dct } & \text { dopachrome tautomerase } \\ \text { Mc1r } & \text { melanocortin 1 receptor } \\ \text { Gapdh } & \text { glyceraldehyde 3-phosphate dehydrogenase } \\ \text { cAMP } & \text { cyclic adenosine monophosphate } \\ \text { PKA } & \text { protein kinase A } \\ \text { CREB } & \text { cAMP-response element binding } \\ \text { p-CREB } & \text { phosphorylated cAMP-response element binding } \\ \text { DOPA } & \text { 3,4-dihydroxy phenylalanine } \\ \text { DHICA } & \text { 5,6-dihydroxyindole-2-carboxylic acid } \\ \text { MTT } & \text { 3-(4,5-dimethylthiazol-2-yl)-2,5-diphenyltetra -zolium bromide } \\ \text { EtOH } & \text { ethanol } \\ \text { EtOAc } & \text { ethyl acetate } \\ \text { DMSO } & \text { dimethyl sulfoxide } \\ \text { PBS } & \text { phosphate-buffer saline } \\ \text { BCA } & \text { bicinchoninic acid }\end{array}$




\section{References}

1. Lin, J.Y.; Fisher, D.E. Melanocyte biology and skin pigmentation. Nature 2007, 445, 843. [CrossRef] [PubMed]

2. Joshi, P.G.; Nair, N.; Begum, G.; Joshi, N.B.; Sinkar, V.P.; Vora, S. Melanocyte-keratinocyte interaction induces calcium signalling and melanin transfer to keratinocytes. Pigm. Cell Res. 2007, 20, 380-384. [CrossRef] [PubMed]

3. Cichorek, M.; Wachulska, M.; Stasiewicz, A.; Tymińska, A. Skin melanocytes: Biology and development. Adv. Dermatol. Allergol. 2013, 30, 30-41. [CrossRef] [PubMed]

4. Park, H.; Kosmadaki, M.; Yaar, M.; Gilchrest, B. Cellular mechanisms regulating human melanogenesis. Cell. Mol. Life Sci. 2009, 66, 1493-1506. [CrossRef] [PubMed]

5. Yoon, J.-W.; Han, J.-M.; Yoon, H.-J.; Ko, W.-S. Inhibitory effects of methanol extract of kaempferia galanga on melanogenesis in b16/f10 melanoma cells. J. Korean Med. Ophthalmol. Otolaryngol. Dermatol. 2013, 26, 1-18. [CrossRef]

6. Lee, Y.; Ku, B.; Kim, D.; Choi, E.-M. Umbelliferone stimulated melanogenesis and increased glutathione level in b16f10 cells. Toxicol. Environ. Health Sci. 2017, 9, 152-160. [CrossRef]

7. Videira, I.F.d.S.; Moura, D.F.L.; Magina, S. Mechanisms regulating melanogenesis. Anais Brasileiros de Dermatologia 2013, 88, 76-83. [CrossRef]

8. Jang, J.-Y.; Kim, H.-N.; Kim, Y.-R.; Kim, B.-W.; Choi, Y.-H.; Choi, B.-T. Studies of inhibitory mechanism on melanogenesis by partially purified asiasari radix in $\alpha$-msh stimulated b16f10 melanoma cells. J. Life Sci. 2010, 20, 1617-1624. [CrossRef]

9. Le Pape, E.; Wakamatsu, K.; Ito, S.; Wolber, R.; Hearing, V.J. Regulation of eumelanin/pheomelanin synthesis and visible pigmentation in melanocytes by ligands of the melanocortin 1 receptor. Pigm. Cell Melanoma Res. 2008, 21, 477-486. [CrossRef]

10. Oh, S.W.; Park, S.-H.; Lee, H.S.; Kang, M.; Lee, S.E.; Yoo, J.A.; Cho, J.Y.; Lee, J. Melanogenic mechanism of ethanolic extract of dalbergia odorifera. Mol. Cell. Toxicol. 2017, 13, 453-459. [CrossRef]

11. Park, H.-Y.; Wu, C.; Yonemoto, L.; Murphy-Smith, M.; Wu, H.; Stachur, C.M.; Gilchrest, B.A. Mitf mediates camp-induced protein kinase c- $\beta$ expression in human melanocytes. Biochem. J. 2006, 395, 571-578. [CrossRef] [PubMed]

12. Kim, D.-S.; Sung, B.-G.; Lee, J.-C.; Lee, B.-K.; Woo, W.-H.; Lim, K.-S. Inhibitory effect of belamcandae rhizoma on the melanogenesis in msh-stimulated b16f10 cells. J. Korean Med. Ophthalmol. Otolaryngol. Dermatol. 2011, $24,25-35$.

13. Gillbro, J.; Olsson, M. The melanogenesis and mechanisms of skin-lightening agents-existing and new approaches. Int. J. Cosmet. Sci. 2011, 33, 210-221. [CrossRef] [PubMed]

14. Kobayashi, T.; Imokawa, G.; Bennett, D.C.; Hearing, V.J. Tyrosinase stabilization by tyrp1 (the brown locus protein). J. Biol. Chem. 1998, 273, 31801-31805. [CrossRef] [PubMed]

15. Orlow, S.J.; Zhou, B.-K.; Drucker, M.; Pifko-Hirst, S.; Chakraborty, A.K.; Pawelek, J.M. High-molecular-weight forms of tyrosinase and the tyrosinase-related proteins: Evidence for a melanogenic complex. J. Investig. Dermatol. 1994, 103, 196-201. [CrossRef]

16. Curto, E.V.; Kwong, C.; Hermersdörfer, H.; Glatt, H.; Santis, C.; Virador, V.; Hearing Jr, V.J.; Dooley, T.P. Inhibitors of mammalian melanocyte tyrosinase: In vitro comparisons of alkyl esters of gentisic acid with other putative inhibitors. Biochem. Pharmacol. 1999, 57, 663-672. [CrossRef]

17. Maeda, K.; Fukuda, M. In vitro effectiveness of several whitening cosmetic components in human melanocytes. J. Soc. Cosmet. Chem. 1991, 42, 361-368.

18. Yokota, T.; Nishio, H.; Kubota, Y.; Mizoguchi, M. The inhibitory effect of glabridin from licorice extracts on melanogenesis and inflammation. Pigm. Cell Res. 1998, 11, 355-361. [CrossRef]

19. Parvez, S.; Kang, M.; Chung, H.S.; Cho, C.; Hong, M.C.; Shin, M.K.; Bae, H. Survey and mechanism of skin depigmenting and lightening agents. Phytother. Res. 2006, 20, 921-934. [CrossRef]

20. Luo, L.; Jiang, L.; Geng, C.; Cao, J.; Zhong, L. Hydroquinone-induced genotoxicity and oxidative DNA damage in hepg2 cells. Chem. Biol. Interact. 2008, 173, 1-8. [CrossRef]

21. Tse, T.W. Hydroquinone for skin lightening: Safety profile, duration of use and when should we stop? J. Dermatol. Treat. 2010, 21, 272-275. [CrossRef] [PubMed] 
22. Yoshimura, M.; Watanabe, Y.; Kasai, K.; Yamakoshi, J.; Koga, T. Inhibitory effect of an ellagic acid-rich pomegranate extract on tyrosinase activity and ultraviolet-induced pigmentation. Biosci. Biotechnol. Biochem. 2005, 69, 2368-2373. [CrossRef] [PubMed]

23. Draelos, Z.D. Skin lightening preparations and the hydroquinone controversy. Dermatol. Ther. 2007, 20, 308-313. [CrossRef] [PubMed]

24. Wijesekara, I.; Pangestuti, R.; Kim, S.-K. Biological activities and potential health benefits of sulfated polysaccharides derived from marine algae. Carbohydr. Polym. 2011, 84, 14-21. [CrossRef]

25. Kim, K.N.; Lee, K.W.; Song, C.B.; Jeon, Y.J. Cytotoxic Activities of Green and Brown Seaweeds Collected from Jeju Island against Four Tumor Cell Lines. J. Food Sci. Nutr. 2006, 11, 17-24. [CrossRef]

26. Feldman, S.; Reynaldi, S.; Stortz, C.; Cerezo, A.; Damonte, E. Antiviral properties of fucoidan fractions from leathesia difformis. Phytomedicine 1999, 6, 335-340. [CrossRef]

27. Lim, J.-H.; Jung, K.-S.; Lee, J.-S.; Jung, E.-S.; Kim, D.-K.; Kim, Y.-S.; Kim, Y.-W.; Park, D.-H. The study on antimicrobial and antifungal activity of the wild seaweeds of jeju island. J. Soc. Cosmet. Sci. Korea 2008, 34, 201-207.

28. Muhammad, S.A.; Muhammad, J.; Muhammad, S.; Muhammad, K.P.; Shaista, H.; Viqar, U.A. Metabolites of marine algae collected from karachi-coasts of arabian sea. Nat. Prod. Sci. 2000, 6, 61-65.

29. Shibata, T.; Kawaguchi, S.; Hama, Y.; Inagaki, M.; Yamaguchi, K.; Nakamura, T. Local and chemical distribution of phlorotannins in brown algae. J. Appl. Phycol. 2004, 16, 291-296. [CrossRef]

30. Zou, Y.; Qian, Z.-J.; Li, Y.; Kim, M.-M.; Lee, S.-H.; Kim, S.-K. Antioxidant effects of phlorotannins isolated from ishige okamurae in free radical mediated oxidative systems. J. Agric. Food Chem. 2008, 56, 7001-7009. [CrossRef]

31. Arnold, T.M.; Targett, N.M. Marine tannins: The importance of a mechanistic framework for predicting ecological roles. J. Chem. Ecol. 2002, 28, 1919-1934. [CrossRef] [PubMed]

32. Heo, S.-J.; Park, P.-J.; Park, E.-J.; Cho, S.K.; Kim, S.-K.; Jeon, Y.-J. Antioxidative effect of proteolytic hydrolysates from ecklonia cava on radical scavenging using esr and $\mathrm{H}_{2} \mathrm{O}_{2}$-induced DNA damage. Food Sci. Biotechnol. 2005, 14, 614-620.

33. Shibata, T.; Nagayama, K.; Tanaka, R.; Yamaguchi, K.; Nakamura, T. Inhibitory effects of brown algal phlorotannins on secretory phospholipase a2s, lipoxygenases and cyclooxygenases. J. Appl. Phycol. 2003, 15, 61-66. [CrossRef]

34. Whitaker, D.M.; Carlson, G.P. Anti-inflammation mechanism of extract from eisenia bicyclis (kjellman) setchell. J. Pharm. Sci. 1975, 64, 1258-1259. [CrossRef] [PubMed]

35. Kim, Y.-J.; Uyama, H. Tyrosinase inhibitors from natural and synthetic sources: Structure, inhibition mechanism and perspective for the future. Cell. Mol. Life Sci. 2005, 62, 1707-1723. [CrossRef] [PubMed]

36. Kobayashi, T.; Urabe, K.; Winder, A.; Jimenez-Cervantes, C.; Imokawa, G.; Brewington, T.; Solano, F.; Garcia-Borron, J.; Hearing, V. Tyrosinase related protein 1 (trp1) functions as a dhica oxidase in melanin biosynthesis. EMBO J. 1994, 13, 5818. [CrossRef] [PubMed]

37. Chakraborty, A.K.; Funasaka, Y.; Slominski, A.; Ermak, G.; Hwang, J.; Pawelek, J.M.; Ichihashi, M. Production and release of proopiomelanocortin (pomc) derived peptides by human melanocytes and keratinocytes in culture: Regulation by ultraviolet b. BBA Mol. Cell Res. 1996, 1313, 130-138. [CrossRef]

38. Saha, B.; Singh, S.K.; Sarkar, C.; Bera, R.; Ratha, J.; Tobin, D.J.; Bhadra, R. Activation of the mitf promoter by lipid-stimulated activation of p38-stress signalling to creb. Pigm. Cell Melanoma Res. 2006, 19, 595-605. [CrossRef] [PubMed]

39. Busca, R.; Ballotti, R. Cyclic amp a key messenger in the regulation of skin pigmentation. Pigm. Cell Melanoma Res. 2000, 13, 60-69. [CrossRef]

40. Levy, C.; Khaled, M.; Fisher, D.E. Mitf: Master regulator of melanocyte development and melanoma oncogene. Trends Mol. Med. 2006, 12, 406-414. [CrossRef] [PubMed]

41. Loir, B.; Pérez, S.C.; Ghanem, G.; Lozano, J.; Garcia-Borron, J.; Jimenez-Cervantes, C. Expression of the mc1 receptor gene in normal and malignant human melanocytes. A semiquantitative rt-pcr study. Cell. Mol. Biol. (Noisy-Le-Grandfrance) 1999, 45, 1083-1092.

42. Azam, M.S.; Choi, J.; Lee, M.S.; Kim, H.R. Hypopigmenting Effects of Brown Algae-Derived Phytochemicals: A Review on Molecular Mechanisms. Mar. Drugs 2017, 15, 297. [CrossRef] [PubMed] 
43. Sanjeewa, K.K.A.; Kim, E.-A.; Son, K.-T.; Jeon, Y.-J. Bioactive properties and potentials cosmeceutical applications of phlorotannins isolated from brown seaweeds: A review. J. Photochem. Photobiol. B Biol. 2016, 162, 100-105. [CrossRef] [PubMed]

44. Kang, H.S.; Kim, H.R.; Byun, D.S.; Son, B.W.; Nam, T.J.; Choi, J.S. Tyrosinase inhibitors isolated from the edible brown alga Ecklonia stolonifera. Arch. Pharm. Res. 2004, 27, 1226-1232. [CrossRef] [PubMed]

45. Jang, M.-S.; Park, H.-Y.; Nam, K.-H. Whitening effects of 4-hydroxyphenethyl alcohol isolated from water boiled with Hizikia fusiformis. Food Sci. Biotechnol. 2014, 23, 555-560. [CrossRef]

46. Joung, E.-J.; Gwon, W.-G.; Shin, T.; Jung, B.-M.; Choi, J.; Kim, H.-R. Anti-inflammatory action of the ethanolic extract from Sargassum serratifolium on lipopolysaccharide-stimulated mouse peritoneal macrophages and identification of active components. J. Appl. Phycol. 2017, 29, 563-573. [CrossRef]

47. Azam, M.S.; Joung, E.-J.; Choi, J.; Kim, H.-R. Ethanolic extract from Sargassum serratifolium attenuates hyperpigmentation through CREB/ERK signaling pathways in $\alpha$-MSH-stimulated B16F10 melanoma cells. J. Appl. Phycol. 2017, 29, 2089-2096. [CrossRef]

48. Fitton, J.H.; Dell'Acqua, G.; Gardiner, V.-A.; Karpiniec, S.S.; Stringer, D.N.; Davis, E. Topical Benefits of Two Fucoidan-Rich Extracts from Marine Macroalgae. Cosmetics 2015, 2, 66-81. [CrossRef]

49. Yan, X.; Chuda, Y.; Suzuki, M.; Nagata, T. Fucoxanthin as the major antioxidant in Hijikia fusiformis, a common edible seaweed. Biosci. Biotechnol. Biochem. 1999, 63, 605-607. [CrossRef]

50. D’Orazio, N.; Gemello, E.; Gammone, M.A.; de Girolamo, M.; Ficoneri, C.; Riccioni, G. Fucoxantin: A treasure from the sea. Mar. Drugs 2012, 10, 604-616. [CrossRef]

51. Sachindra, N.M.; Sato, E.; Maeda, H.; Hosokawa, M.; Niwano, Y.; Kohno, M.; Miyashita, K. Radical scavenging and singlet oxygen quenching activity of marine carotenoid fucoxanthin and its metabolites. J. Agric. Food Chem. 2007, 55, 8516-8522. [CrossRef] [PubMed]

52. Wang, J.; Chen, S.; Xu, S.; Yu, X.; Ma, D.; Xu, X. In vivo induction of apoptosis by fucoxanthin, a marine carotenoid, associated with down-regulating STAT3/EGFR signaling in sarcoma 180 (S180) xenografts-bearing mice. Mar. Drugs 2012, 10, 2055-2068. [CrossRef]

53. Heo, S.J.; Yoon, W.J.; Kim, K.N.; Oh, C.; Choi, Y.U.; Yoon, K.T.; Kang, D.H.; Qian, Z.J.; Choi, I.W.; Jung, W.K. Anti-inflammatory effect of fucoxanthin derivatives isolated from Sargassum siliquastrum in lipopolysaccharide-stimulated RAW 264.7 macrophage. Food Chem. Toxicol. 2012, 50, 3336-3342. [CrossRef] [PubMed]

54. Jung, H.A.; Islam, M.N.; Lee, C.M.; Jeong, H.O.; Chung, H.Y.; Woo, H.C.; Choi, J.S. Promising antidiabetic potential of fucoxanthin isolated from the edible brown algae Eisenia bicyclisand Undaria pinnatifida. Fish. Sci. 2012, 78, 1321-1329. [CrossRef]

55. Shimoda, H.; Tanaka, J.; Shan, S.J.; Maoka, T. Anti-pigmentary activity of fucoxanthin and its influence on skin mRNA expression of melanogenic molecules. J. Pharm. Pharmacol. 2010, 62, 1137-1145. [CrossRef] [PubMed]

56. Lee, M.S.; Yoon, H.D.; Kim, J.I.; Choi, J.S.; Byun, D.S.; Kim, H.R. Dioxinodehydroeckol inhibits melanin synthesis through PI3K/Akt signalling pathway in alpha-melanocyte-stimulating hormone-treated B16F10 cells. Exp. Dermatol. 2012, 21, 471-473. [CrossRef]

57. Kim, K.N.; Yang, H.M.; Kang, S.M.; Ahn, G.N.; Roh, S.W.; Lee, W.; Kim, D.K.; Jeon, Y.J. Whitening Effect of Octaphlorethol A Isolated from Ishige foliacea in an In Vivo Zebrafish Model. J. Microbiol. Biotechnol. 2015, 25, 448-451. [CrossRef] [PubMed]

58. Song, Y.S.; Balcos, M.C.; Yun, H.Y.; Baek, K.J.; Kwon, N.S.; Kim, M.K.; Kim, D.S. ERK Activation by Fucoidan Leads to Inhibition of Melanogenesis in Mel-Ab Cells. Korean J. Physiol. Pharmacol. 2015, 19, 29-34. [CrossRef]

59. Yoon, W.-J.; Kim, M.-J.; Moon, J.-Y.; Kang, H.-J.; Kim, G.-O.; Lee, N.H.; Hyun, C.-G. Effect of palmitoleic acid on melanogenic protein expression in murine b16 melanoma. J. Oleo Sci. 2010, 59, 315-319. [CrossRef]

60. Kim, M.-J.; Kim, D.S.; Yoon, H.-S.; Lee, W.J.; Lee, N.H.; Hyun, C.-G. Melanogenesis inhibitory activity of korean undaria pinnatifida in mouse b16 melanoma cells. Interdiscip. Toxicol. 2014, 7, 89-92. [CrossRef]

(C) 2019 by the authors. Licensee MDPI, Basel, Switzerland. This article is an open access article distributed under the terms and conditions of the Creative Commons Attribution (CC BY) license (http:/ / creativecommons.org/licenses/by/4.0/). 